\title{
DETERMINANTS OF FOREIGN EXCHANGE RESERVES IN INDIA
}

\author{
Bhakri Suman 1, Verma Aman *2 ${ }^{*}$ iD \\ ${ }^{1}$ Associate Professor, Department of Commerce, Shri Ram College of Commerce, University of \\ Delhi, India \\ *2 Research Scholar, Ph.D. Department of Commerce, Delhi School of Economics, University of \\ Delhi, India
}

DOI: https://doi.org/10.29121/granthaalayah.v9.i2.2021.3493

Article Type: Research Article

Article Citation: Bhakri, S., and Verma, A.. (2021). DETERMINANTS OF FOREIGN EXCHANGE RESERVES IN INDIA. International Journal of Research -GRANTHAALAYAH, 9(2), 229-240.

https://doi.org/10.29121/granthaa layah.v9.i2.2021.3493

Received Date: 25 January 2021

Accepted Date: 28 February 2021

Keywords:

Foreign Exchange Reserves

Liquidity and Safety

Determinants

Exchange Rate

Reserve Adequacy

GDP

Double Log Regression Model

\section{ABSTRACT}

Motivation/Background: A country holds foreign exchange reserves for maintaining liquidity and safety. The country possess certain amount of foreign reserves to meet their day to day operations and to meet the unforeseen contingencies. The optimum level of reserves helps a country to be self-reliant and have a self-sufficiency to meet their payment obligations.

Methods: The paper has used double log regression model to find out the relevant and significant determinants of foreign exchange reserves in India. There are several factors like exchange rate regime, quality of institutions, history of financial crisis, degree of openness, country to country differences, dominate in conceptualizing and measuring reserve adequacy for any country.

Results: The results of the current study shows that inflow of FDI, exchange rate, exports, short term debt and time affects the value of foreign exchange reserves in India.

Conclusion: The study concludes that there are four major macroeconomic factors that affect the value of foreign exchange reserves and it is statistically significant also. The current paper can be of great use for the policy makers of India, in a way that they should consider the relevant determinants of foreign exchange reserves while accumulating it.

\section{INTRODUCTION}

The expansion in the volume of export, import and highly volatile capital flows in the form of investments, raised the concern for managing the foreign exchange reserves. According to International Monetary Fund, "Foreign exchange reserves are the external assets, which are readily available to and controlled by the monetary authorities of respective countries for direct financing of external payments imbalances and for indirectly regulating the magnitudes of such imbalances through intervention in exchange markets to affect the currency exchange rate, and/or for other purposes." Most countries rely on this definition for all the operational purposes, whether it is for export, import, or for FDI, FII, etc.

Foreign exchange reserves are called reserve assets in the balance of payments and are recorded in the capital account. The reserves are labelled as 'reserve assets' under assets by 'functional category'. In terms of financial assets classifications, the reserve assets can be classified as Gold bullion, unallocated gold accounts, currency, reserve position in the IMF, special drawing rights, interbank position, other deposits, other transferable deposits, debt securities, loans, equity (listed and unlisted), investment fund shares and financial derivatives, such as forward

(C) 2021 The Author(s). This is an open access article distributed under the terms of the Creative Commons Attribution License, which permits unrestricted use, distribution, and reproduction in any medium, provided the original author and source are credited. 
contracts and options. There is no corresponding item for reserve assets in liabilities of the International Investment Position. Usually, when the monetary authority of a country has some kind of liability, this will be included in other categories, such as Other Investments. In the Central Bank's Balance Sheet, foreign exchange reserves are assets, along with domestic credit. India's level of foreign exchange reserves has increased to an unprecedented scale post reform period. In 1991, it was merely US \$ 5.8 billion and during the period of liberalization, it increased substantially. In 1994, the foreign exchange reserves stood at approximately US \$ 19 billion, showing an almost 4 times growth. The level of foreign exchange reserves stood at US \$ 360.176 billion in March 2016 and further rose to US \$ 433.71 billion in September 2019.

The countries want to hold foreign exchange reserves since the future is uncertain. Even if the monetary authorities could predict with absolute certainty when foreign receipts and payments would be made, they might still have to hold some receipts in the form of financial assets in anticipation of meeting payment obligations. Therefore, the monetary authorities should consider the patterns and amounts of future foreign exchange transactions, which may be in large in value, and thus it behoves them to maintain sizeable balance of reserves at all times.

A country holds reserves for maintaining liquidity and safety. Liquidity and safety meaning thereby, a country should possess certain enough amount of foreign exchange reserves to meet their day to day operations like trading and also to assure their safety in times of crises. The optimum level of reserves helps a country to be self-reliant and have a self-sufficiency to meet their payment obligations, along with creating a vulnerability which means sensitivity to the stock of reserves, i.e., if reserve level falls below optimum level, a country should become alert on accumulation of reserves otherwise their currency would appreciate which would adversely affect the exports of the country and thereby GDP, which might lead to a situation of crises. Apart from self-reliance, self-sufficiency and vulnerability, there is a 'buffer', which acts a shock absorber in times of crises for which certain costs are to be paid like sterilization costs, losses in central bank's balance sheet, but it helps in bringing economic stability.

There is no single level of reserves that is universally considered either sufficient or optimal since the circumstances vary from country to country. Advanced economies with floating currencies and highly liquid and stable financial market access in domestic currency tend to derive insignificant value from holding precautionary reserves. On the other hand, countries where currencies are less liquid and having less stable financial markets tend to hold high level of reserves as it may reduce both the risk and impact of current account shocks and capital account crises.

It is very difficult to devise a universally applicable method of optimum reserve determination as countries face differential conditions relating to degree of openness, exchange rate regime, quality of institutions and the history of financial crisis. These factors dominate in conceptualizing and measuring reserve adequacy for a country. Any miscalculation relating to these factors may worsen the external creditworthiness and can also disrupts the capital flows of an economy. The multiplicity of these factors causing variations in reserve flows and the intensity of such variations in recent years have highlighted the necessity of operationalizing on optimum level of reserves.

Economists have made a lot of efforts to present an optimizing framework for maintaining an appropriate level of foreign exchange reserves. There are various viewpoints as far as the level of optimum reserves is concerned. Whereas one of the viewpoints suggest that the optimum level of reserves is that level where marginal social costs equal marginal social benefit, another viewpoint focusses on the level of reserves where the marginal productivity of real resources equals marginal productivity of reserves plus interest earned on reserve assets. In simple words, foreign exchange reserves are said to be adequate when the level of foreign exchange reserves ensures sustainable balance of payments and macroeconomic adjustment resulting from reversals in short term foreign capital flows or external price shocks.

In order to determine the appropriate or optimal level of reserves, the following indicators have been suggested by various economists and academicians. These are as follows:

1) Trade based indicator- These indicators are also known as import based indicators or it can also be termed as ratio of non-gold foreign exchange reserves to imports. These indicators basically got popularity after the World War II and it was suggested by Keynes and Triffin (1947) and IMF (1953). The measure suggests certain number of months of import bills is covered by reserves, meaning thereby how many months a country can support its current level of imports if all other capital flows tend to cease. Reserves covering three months of imports has been conventionally regarded as adequate and considered as a useful indicator for predicting future international payments obligations. While three month of import cover is assumed as the minimum threshold, six months of import cover could be deemed as safe and viable for developing 
countries. This measure is suitable for low income countries which are vulnerable to current account shocks and do not have significant access to capital markets.

$$
\mathrm{AFR}=\mathrm{FR} \div \mathrm{IM}
$$

Where, AFR is Adequate Foreign Exchange Reserves, FR is Foreign Reserves and IM is Import bill (Sahu, 2015). Despite its popular use as a reserve adequacy indicator, import cover has got some serious practical limitations like it is purely based on merchandise trade and does not include other components of current account such as services, transfers and invisibles. In order to overcome such limitations, reserves covering six months of merchandise trade as well as one year invisible payments may be considered optimal for an emerging economy. Also, the adequacy of reserves is influenced by the economic situation of a country. Short term debts may result in sudden and sharp capital outflows which are excluded in this method.

2) Debt-based indicator- The famous Greenspan-Guidotti rule, named after Alan Greenspan and Pablo Guidotti, is a debt-based indicator of determining the adequate level of reserves. It measures the extent of external drain that a country is exposed to at a particular point of time. They said that developing countries should amass their reserves equal to all external debt maturing in the next year, i.e., all short-term debts. Short term debt is considered healthy and in simple words, it means to maintain a level of reserves that meets the shortterm debt with remaining maturity. However, this rule does not take into account the main source of reserve demand, i.e., imports. Without trade element, debt-based rules are believed to underestimate the ideal reserve requirements of a country.

$$
\mathrm{AFR}=\mathrm{FR} \div \mathrm{SFD}
$$

Where, AFR is Adequate foreign exchange reserves, FR is foreign exchange reserves and SFD is short term foreign debt (Sahu, 2015).

3) Money-based indicator- Kamnisky (1999) employed the monetary aggregates and he measured foreign exchange reserve adequacy level as the ratio of foreign exchange reserves to broad money or what we call as base money (M2). The Net Foreign Exchange Assets (NFEA) to currency ratio is also a money-based indicator and it helps in predicting the sustainability of reserve flows in a country. Money based indicators are useful for countries that face a high risk of capital flight, i.e., it is a good interpreter of crises. These indicators are deemed to be better predictors of reserves in countries with full capital account convertibility. Under full capital account convertibility, citizens possess the autonomy to convert their domestic currency into foreign currencies and vice versa. However, this measure suffers from certain limitations where on one hand, in developed economies, demand for money is stable and confidence in domestic currency is high, there is no requirement of holding high level of reserves, on the other hand, emerging and developing economies (EDEs), demand for money is unstable and confidence in domestic currency tends to be low, maintaining a high level of reserves could provide a cushion to them in situation of crises.

$$
\mathrm{AFR}=\mathrm{FR} \div \mathrm{M} 2
$$

Where, AFR is Adequate foreign exchange reserves, FR is Foreign exchange reserves and M2 is Broad money or base money. The Reserve Bank of India Act, 1934 stipulates a minimum of 40 percent net foreign assets backed by domestic currency in India. However, given current realities, a minimum 70 percent coverage of foreign currency assets for domestic currency in circulation is recommended.

4) Reserve Drainer Approach- Apart from all the indicators mentioned above, there's one more which was suggested by Shcherbakov in 2002 after he examined the Russian foreign exchange outflows experience. He combined all the above explained determinants of reserves which are import bills, short term foreign debt and broad money to measure foreign exchange reserve holdings. Shcherbakov (2002) suggested that once these variables are matched by available external reserves, then external shocks would be cushioned in any economy.

$$
\mathrm{AFR}=\mathrm{FR} \div(\mathrm{IM}+\mathrm{SFD}+\mathrm{M} 2)
$$


Where, AFR is Adequate foreign exchange reserves, IM is Import bills, SFD is Short term foreign debt and M2 is broad or base money.

The current paper looks into the various determinants of foreign exchange reserves in India. Determinants are the factors that affect the level of foreign exchange reserves. For this purpose double log regression model has been used to find out the elasticity among foreign exchange reserves and its various determinants. The study has reviewed some pieces of literature before analysing the impact of various determinants on foreign exchange reserves.

\section{LITERATURE REVIEW}

Green and Torgerson (2007) in their study emphasized on three determinants of foreign exchange reserves, namely import, money supply and short term debt. They stated the fact that developing economies should hold reserves equal to minimum 3 months of import bill. In other words, a country should hold reserves equal to three months of import bill. However, they are also of the opinion that this determinant is not much relevant for economies with capital market access. As far as the short term debt is concerned, they have stated that, a country should amass reserves equal to the total value of debt maturing in the next year. So they calculated the ratio of reserves/ short term debt, and based on their calculations, the ratio of reserves to short term debt should always be more than one. Countries with capital account convertibility should use money supply i.e., M2 as the determining factor for adequate level of reserves, and they have also emphasized on the fact that a country should hold reserves in a range of 5-20\% in case of the flexible exchange rate system. After that, Green and Torgerson put the relative weights on each of the variables, and estimated the demand for foreign reserves in a multivariate setting. Sahu (2015) also provided similar determinants of foreign exchange reserves. The difference between the two studies of Green and Torgerson (2007) and Sahu (2015) is where former focussed on seven developing economies and latter on India only. Sahu has also discussed that import coverage ratio should be equal to minimum three months. Ozyildirim and Yaman (2005) questioned on the appropriate level of reserves needed to protect against an exogenous shock. It was traditionally found by some of the economists that there are broadly two measures namely, reserves covering at least 3 months of import and reserves equal to $20 \%$ of broad money (Norris et. al, 2011). Kapteyn(2001) suggested that reserves equal to 5-20\% of M2, depending upon the exchange rate, is an appropriate buffer. Barnichon (2008) noted certain key parameters in the small states, namely, the size and persistence of shocks, the importance of export sector and the degree of risk average, which can have significant impact on the level of foreign exchange reserves.

Sen(2005) in his article, looked at the volatility that comes with the inflow of foreign capital. There are basically two types of inflows, Foreign Direct Investment (FDI) and Foreign Institutional Investment (FII). FDI is considered to be less volatile as compared to FII, as it helps in enhancing the productive capacity and enables the upgradation of technology in any country. Whereas FII and NRI deposits can influence the strength of the economy since they are much more volatile in nature. FDI and FII, both are considered to be important determinants of foreign exchange reserves, since FII is a volatile component, the present study excludes it for the purpose of analysis.

Dash and Narayanan (2011) have highlighted the key determinants imports, nominal exchange rate of foreign exchange reserves in India by using Maximum Likelihood Vector Error Correction Model (VECM) of Johansen (1995) using monthly and annual data. They included the rupee-dollar bilateral nominal exchange rate and also the capital flows in India which is nothing but FDI and FII.

The study by Polterovich and Popov (2003) aims at the accumulation of foreign exchange reserves (FER) which positively influences the economic growth of a developing economy by increasing the investment, capital productivity and thereby GDP. It is widely known that devaluation of a currency can increase output in the short run, bringing actual output above the potential level, it is generally assumed that in the long run growth rates of output do not depend on the exchange rate, rather the exchange rate itself in the long run is considered as an endogenous variable determined by the growth rates of prices and outputs in two countries. The exchange rate is one of the key determinants of foreign exchange reserves, and the devaluation and depreciation leads to increase in exports in the short run, but in the long run it will adversely affect the growth of the economy. 


\section{MATERIALS AND METHODS}

\subsection{DATA}

Annual time series data for the period of 1991-2017 has been used for the present study. Secondary data has been used for the purpose of analysis. The data has been collected from the official websites, statistical department of the central bank, ministry of finance, Worldbank data bank, International Monetary Fund(IMF)

\subsection{VARIABLES}

After reviewing the various pieces of literature, it has been concluded that there are six determinants of foreign exchange reserves namely, import, export, short term debt, money supply, FDI and exchange rate. Since the current paper analyses the India's scenario as far as the determinants of foreign exchange reserves are concerned. Since India is a developing economy and it is highly dependent on gulf countries for its oil requirements, there are two categories of import namely, oil import and non-oil import. So, for the purpose of analysis both categories of imports have been considered. Besides the above variables, the present paper also considers money supply M3, external commercial borrowing (ECB), long term debt and rate of interest for the purpose of analysis.

The current study examines the period 1991-2017. We have included oil import, non-oil import, exports, foreign direct investment (FDI), external commercial borrowing (ECB), short term debt, long term debt, money supply, exchange rate, rate of interest and time.

Table 3.1 shows all the variables in a tabular format and their labels and expected sign attached to each of the variables. Th signs attached reflect the impact of these variables on the value of foreign exchange reserves. All the variables are in logarithm, in order to examine the elasticity of foreign exchange reserves vis-a-vis other variables.

Table 3.1: Label and Expected Sign of Variables

\begin{tabular}{|c|c|c|c|}
\hline S. No. & Variable & Label & Expected Sign \\
\hline 1 & Oil Import & LOIM & - \\
\hline 2 & Non-Oil Import & LNIM & - \\
\hline 3 & Export & LEXP & + \\
\hline 4 & Foreign Direct Investment & LFDI & + \\
\hline 5 & External Commercial Borrowing & LECB & + \\
\hline 6 & Short Term Debt & LSTD & + \\
\hline 7 & Long Term Debt & LLTD & + \\
\hline 8 & Nominal Exchange Rate & LNEX R & - \\
\hline 9 & Rate of Interest & LROI & + \\
\hline 10 & Money Supply, M3 & LM3 & + \\
\hline
\end{tabular}

\subsection{METHODOLOGY}

The current study has employed double log regression model to find out the significant determinants of foreign exchange reserves in India. This model is a better estimate of finding out the elasticity between the dependent and independent variable.

For estimating the elasticity, the functional form of the model is as follows:

$$
\operatorname{Ln} Y=f\left(\sum_{i=1}^{n} \operatorname{Ln} X_{i}\right)
$$

Where, $\operatorname{LnY}=$ Natural log of variable $Y$

$\operatorname{Ln} X_{\mathrm{i}}=$ Natural $\log$ of variable $\mathrm{X}$

$\mathrm{i}=$ Number of variables

The estimating equation is as follows: 


$$
L n Y=a+\sum_{i=1}^{n} b_{i} \operatorname{Ln} X_{i}+\mu_{t}
$$

Where,

LnY= Natural log of variable $Y$

$\mathrm{a}=$ intercept

$\mathrm{b}=$ elasticity

LnX= Natural $\log$ of variable $\mathrm{X}$

$\mu_{\mathrm{t}}=$ error term

\subsection{HYPOTHESES}

These are the hypotheses which have been tested at 5\% level of significance in the current paper:

$\mathrm{H} 1_{0}$ : $\quad$ There is no impact of oil import on foreign exchange reserves

$\mathrm{H} 2_{0}$ : There is no impact of non-oil import on foreign exchange reserves

$\mathrm{H}_{0}$ : $\quad$ There is no impact of exports on foreign exchange reserves

$\mathrm{H}_{4}$ : $\quad$ There is no impact of foreign direct investment on foreign exchange reserves

H5: $\quad$ There is no impact of external commercial borrowings on foreign exchange reserves

$\mathrm{H6}_{0}$ : $\quad$ There is no impact of short term debt on foreign exchange reserves

$\mathrm{H7}_{0}$ : $\quad$ There is no impact of long term debt on foreign exchange reserves

$\mathrm{H}_{0}$ : $\quad$ There is no impact of nominal exchange rate on foreign exchange reserves

$\mathrm{H} 9_{0}: \quad$ There is no impact of rate of interest on foreign exchange reserves

$\mathrm{H} 10_{0}$ : There is no impact of money supply on foreign exchange reserves

\section{RESULTS AND DISCUSSION}

For the purpose of analysis double log regression model has been used, in order to understand the relationship between foreign exchange reserves and eleven independent variables. The model has been further used to find out the significance of these variables. Four models, including one auxiliary model have been devised for the purpose of analysis.

\section{Model A:}

The functional equation of model A is as follows:

$$
\text { LFER }=f(L O I M, L N I M, L E X P, L F D I, L E C B, L S T D, \text { LLTD }, \text { LNEX R, LROI, LM3,T) }
$$

Where, LFER = Natural log of foreign exchange reserves

LOIM = Natural log of Oil Import

LNIM = Natural log of Non-Oil Import

LEXP = Natural log of Exports

LFDI = Natural log of Foreign Direct Investment

LECB = Natural log of External Commercial Borrowing

LSTD = Natural log of Short Term Debt

LLTD = Natural log of Long Term Debt

LNEX R = Natural log of Nominal Exchange Rate

LROI = Natural log of Rate of Interest

LM3 = Natural log of Money Supply

$\mathrm{T}=$ Time period (1991-2017)

The estimating equation to run the regression is given below:

$$
\begin{gathered}
\text { LFER }=a+b_{1} T+b_{2} L O I M+b_{3} L N I M+b_{4} L E X P+b_{5} L F D I+b_{6} L E C B+b_{7} L S T D+b_{8} L L T D+b_{9} L N E X R \\
+b_{10} L R O I+b_{11} L M 3
\end{gathered}
$$


Where, $\mathrm{a}=$ intercept or initial level of foreign exchange reserves

$\mathrm{b}_{1}=$ elasticity between time and foreign exchange reserves

$b_{2}=$ elasticity between oil import and foreign exchange reserves

$b_{3}=$ elasticity between non-oil import and foreign exchange reserves

$\mathrm{b}_{4}=$ elasticity between exports and foreign exchange reserves

$\mathrm{b}_{5}=$ elasticity between foreign direct investment and foreign exchange reserves

$\mathrm{b}_{6}=$ elasticity between external commercial borrowing and foreign exchange reserves

$\mathrm{b}_{7}=$ elasticity between short term debt and foreign exchange reserves

$\mathrm{b}_{8}=$ elasticity between long term debt and foreign exchange reserves

$b_{9}=$ elasticity between nominal exchange rate and foreign exchange reserves

$b_{10}=$ elasticity between rate of interest and foreign exchange reserves

$\mathrm{b}_{11}=$ elasticity between money supply and foreign exchange reserves

Table 4.1: Regression Statistics of Model A:

\begin{tabular}{|c|c|c|c|c|}
\hline & Coefficients & Standard Error & t Stat & P-value \\
\hline Intercept & -184.4782164 & 97.50643198 & -1.89195946 & 0.077962395 \\
\hline LOIM & -0.069911552 & 0.222542525 & -0.314149182 & 0.757734568 \\
\hline LNIM & -0.005907421 & 0.370458008 & -0.015946264 & 0.987487431 \\
\hline LEXP & 0.738351055 & 0.437104489 & 1.689186621 & 0.11185592 \\
\hline LFDI & 0.292206172 & 0.075836292 & 3.853117866 & 0.001563933 \\
\hline LECB & -0.110248321 & 0.446896981 & -0.246697395 & 0.808486759 \\
\hline LSTD & -0.136990146 & 0.155213137 & -0.88259376 & 0.391381009 \\
\hline LLTD & -0.343362021 & 0.542887776 & -0.632473296 & 0.536600293 \\
\hline LNEX R & -0.956058331 & 0.595735589 & -1.60483669 & 0.129372863 \\
\hline LROI & -0.03559806 & 0.04630815 & -0.768721267 & 0.453992853 \\
\hline LM3 & 0.040507646 & 0.085054741 & 0.476253825 & 0.640756361 \\
\hline T & 0.097485338 & 0.051226084 & 1.903041024 & 0.076406985 \\
\hline
\end{tabular}

Using the regression statistics of model A from table 4.1, the following estimated equation is as follows:

$$
\begin{array}{rl}
\text { LFER }=-184 & 4782164+0.097485338 T+(-0.069911552 L O I M)+(-0.005907421 L N I M) \\
& +0.738351055 L E X P+0.292206172 L F D I+(-0.110248321 \text { LECB })+(-0.136990146 \text { LSTD }) \\
& +(-0.343362021 L L T D)+(-0.956058331 L N E X R)+(-0.03559806 \text { LROI })+0.040507646 L M 3
\end{array}
$$

Table 4.1 represents regression statistics of Model A, where the initial level of foreign exchange reserves have been observed negative. There are four variables, namely oil import, non-oil import, external commercial borrowings and money supply are found highly insignificant as their P-value is very much high as compared to others. These variables are highlighted in bold. So, now we will be going to first tackle these insignificant variables.

Oil import (LOIM) and Non-Oil Import (NOIM) are not coming out to be statistically significant because import prices are highly volatile, therefore oil import cannot be a significant determinant of foreign exchange reserves. The coefficients of oil import and non-oil import are coming out be around $6 \%$ and $0.05 \%$ respectively and their standard error, a measure of volatility, is around $22 \%$ and $37 \%$ respectively. Similar results have been observed in case of external commercial borrowings and money supply, M3.

On the basis of above results, the model B has eliminated these four insignificant variables.

\section{Model B:}

The functional equation of model B is as follows:

$$
L F E R=f(L E X P, L F D I, L S T D, L L T D, L N E X R, L R O I, T)
$$




\section{Bhakri Suman, and Verma Aman}

The estimating equation of model $\mathrm{B}$ is given below:

$$
L F E R=a+b_{1} T+b_{4} L E X P+b_{5} L F D I+b_{7} L S T D+b_{8} L L T D+b_{9} L N E X R+b_{10} L R O I
$$

Table 4.2: Regression Statistics of Model B:

\begin{tabular}{|c|c|c|c|c|}
\hline & Coefficients & Standard Error & t Stat & P-value \\
\hline Intercept & -189.3881458 & 71.58540646 & -2.645625068 & 0.015949879 \\
\hline LEXP & 0.645477304 & 0.243999985 & 2.645398955 & 0.015957616 \\
\hline LFDI & 0.296139599 & 0.060971817 & 4.8569915 & 0.000109504 \\
\hline LSTD & -0.177008197 & 0.117458956 & -1.506979137 & 0.148262716 \\
\hline LLTD & -0.367105846 & 0.320958183 & -1.143780921 & 0.266921006 \\
\hline LNEX R & -1.085508117 & 0.401761845 & -2.701869607 & 0.014132164 \\
\hline LROI & -0.038213912 & 0.03799904 & -1.005654657 & 0.327218273 \\
\hline T & 0.10031299 & 0.037858529 & 2.649680085 & 0.015811731 \\
\hline
\end{tabular}

Using the regression statistics of model B form table 4.2, the estimated equation is:

$$
\begin{gathered}
\text { LFER }=-189.38+0.1003 T+0.645 L E X P+0.296 L F D I+(-0.177) L S T D+(-0.367) L L T D+(-1.085) L N E X R \\
+(-0.038) L R O I
\end{gathered}
$$

Table 4.2 represents regression statistics of model B, the analysis clearly indicates rate of interest variable is highly insignificant as compared to other variables. Similarly, short term debt and long term debt are also seen to be insignificant, but the magnitude of them is less as compared to rate of interest. Further, exports, foreign direct investment, exchange rate and time variables are found to be highly significant and can be considered as reliable determinants of foreign exchange reserves in India.

Auxiliary regression model has been used to check the multicollinearity between two independent variables, namely short term debt and long term debt, which sums up to total debt. Short term debt is regressed on long term debt and rate of interest in the auxiliary model. There is a need to examine whether these variables are coming out to be insignificant due to multicollinearity.

\section{Two Stage Least Square Model (2SLS)}

In two stage least square model, first auxiliary regression analysis has been done, where short term debt is regressed on long term debt and rate of interest, to check if there is any multicollinearity among the variables. The model has two stages:

Stage 1: A) Auxiliary Regression- In the first stage of 2SLS model, short term debt (LSTD) is regressed on long term debt (LLTD) and rate of interest (LROI).

B) To derive and embed the predicted short term debt (Pre-LSTD) from the auxiliary regression into the structural equation.

Stage 2: Structural equation model

The above two stages denotes the two stage least square model, which helps in determining the predicted value of short term debt by regressing it on long term debt and rate of interest. After substituting this predicted value of short term debt into the structural equation, will finally help in finding the determinants of foreign exchange reserves.

Stage 1: Auxiliary Regression:

The following is the functional equation of the auxiliary regression model:

$$
L S T D=f(L L T D, L R O I)
$$

Where, $\mathrm{LSTD}=$ Natural log of short term debt

LLTD $=$ Natural log of long term debt

LROI= Natural log of rate of interest 
The estimating equation is given below:

$$
L S T D=a+b_{11} L L T D+b_{12} L R O I+\mu_{t}
$$

Where, $\mathrm{LSTD}=$ Natural log of short term debt

$\mathrm{a}=$ intercept of short term debt

$\mathrm{b}_{11}=$ elasticity between short term debt and long term debt

$\mathrm{b}_{12}=$ elasticity between short term debt and rate of interest

$\mu_{\mathrm{t}}=$ error term

Table 4.3: Regression Statistics of the auxiliary model:

\begin{tabular}{|c|c|c|c|c|}
\hline & Coefficients & Standard Error & t Stat & P-value \\
\hline Intercept & -15.95255924 & 1.8759181 & -8.503867646 & $1.05274 \mathrm{E}-08$ \\
\hline LLTD & 2.136619818 & 0.157315924 & 13.58171356 & $9.24509 \mathrm{E}-13$ \\
\hline LROI & 0.070248311 & 0.101759544 & 0.690336338 & 0.496605096 \\
\hline
\end{tabular}

Using the regression statistics of auxiliary regression model from table 4.3, the following estimated equation is:

$$
L S T D=-15.95255924+2.136619818 L L T D+0.070248311 L R O I
$$

\section{(P-Value) $1.05274 E-08 \quad 9.24509 E-13 \quad 0.496605096$}

Table 4.3 represents the regression statistics of the auxiliary model. The table clearly indicates that long term debt is highly significant determinant of short term debt, meaning thereby, multicollinearity exists between short term debt and long term debt. As far as the rate of interest is concerned, it is found to be highly insignificant, hence short term debt is not influenced by rate of interest. The rate of interest is being finally eliminated from the main model as it is found to be non-reliable determinant of foreign exchange reserves.

- In step one of 2SLS model, it has been witnessed by auxiliary regression model that short term debt is dependent on long term debt.

- In step two, predicted values of short-term debt have been derived for each observation and then embedded these values into the structural equation.

- Finally predicted values of short-term debt from the auxiliary regression model have been substituted into the actual structural model.

Stage 2: Structural equation model

Finally the regression is run using the predicted value of short term debt, the functional equation of the structural equation of the model is as follows:

$$
L F E R=f(L E X P, L F D I, \text { PreLSTD }, L N E X R, T)
$$

Where, $L F E R=$ Natural log of foreign exchange reserves

LEXP= Natural log of exports

LFDI= Natural log of foreign direct investment

Pre-LSTD = Natural log of predicted value of short term debt

LEX $\mathrm{R}=$ Natural log of nominal exchange rate

$\mathrm{T}=$ Time(1991-2017)

The following is the estimating equation of the structural model:

$$
L F E R=a+b_{1} T+b_{4} L E X P+b_{5} L F D I+b_{13} \text { PreLSTD }+b_{9} L N E X R+\mu_{t}
$$

Where, $b_{1}=$ elasticity between time and foreign exchange reserves

$\mathrm{b}_{4}=$ elasticity between exports and foreign exchange reserves 
$b_{5}=$ elasticity between foreign direct investment and foreign exchange reserves

$b_{13}=$ elasticity between predicted value of short term debt and foreign exchange reserves

$\mathrm{b}_{9}=$ elasticity between nominal exchange rate and foreign exchange reserves

$\mu_{\mathrm{t}}=$ error term

Table 4.4: Regression Statistics of the structural model:

\begin{tabular}{|c|c|c|c|c|}
\hline & Coefficients & Standard Error & t Stat & P-value \\
\hline Intercept & -225.8607885 & 67.74607553 & -3.33393 & 0.00315 \\
\hline LEXP & 0.469531023 & 0.215518925 & 2.178607 & 0.040898 \\
\hline LFDI & 0.285924378 & 0.059212999 & 4.828743 & $8.99 \mathrm{E}-05$ \\
\hline Pre-LSTD & -0.358297682 & 0.082638312 & -4.33573 & 0.000291 \\
\hline LNEX R & -0.768912529 & 0.344331954 & -2.23306 & 0.036559 \\
\hline T & 0.117599672 & 0.035389085 & 3.323049 & 0.003231 \\
\hline
\end{tabular}

Using the regression statistics of structural equation model from table 4.4, the following estimated equation is:

$$
L F E R=-225.86+0.1176 T+0.47 L E X P+0.286 L F D I+(-0.358) \operatorname{PreLSTD}+(-0.768) L N E X R+\mu_{t}
$$

Table 4.4 represents regression statistics of structural model. All the variables in the structural model are found to be significant. It can be concluded that all variables, namely, exports, foreign direct investment, nominal exchange rate, short term debt and long term debt are the reliable determinants of foreign exchange reserves in India. All the variables are highly significant as P-value of all of them is less than 0.05 .

On the basis of the table, it can be interpreted that if value of exports increase by $1 \%$, then foreign exchange reserves will increase by $0.469 \%$ and it is statistically significant also (P-value $=0.040898)$. Foreign direct investment is also coming out to be a highly significant variable and with $1 \%$ increase in FDI, foreign exchange reserves would increase by $0.285 \%$ and it is statistically significant also (P-value= 8.99E-05).

Short term debt is also a very significant variable (P-value= 0.000291 ). There would be a fall of over $0.358 \%$ in the value of foreign exchange reserves due to a $1 \%$ increase in short term debt. A major determinant of foreign exchange reserves is nominal exchange rate. It clearly shows that with a 1\% depreciation of rupee, foreign exchange reserves deplete to the tune of almost $0.7689 \%$ and it is highly significant also (P-value $=0.036559$ ).

Quality of goods and services, their variety and quantity leads to strengthening of the currency. It is highly undesirable on the part of the policy makers to depreciate the currency to increase exports. However, generally the policies are favourable in spite of depreciation of exchange rate and short term debt, still foreign exchange reserves are growing at the rate of $11 \%$ and it is statistically significant also (P-value $=0.003231$ ).

So, for the past 27 years, foreign exchange reserves in case of India have been well managed. To examine the impact of long term debt, there is need to multiply the coefficient of LLTD from the auxiliary regression model by Pre-LSTD. This will give the impact of long term debt on foreign exchange reserves. The coefficient of LLTD is around 2.13 and the coefficient of Pre-LSTD is around -0.358. After multiplying these two coefficients, the impact of long term debt on foreign exchange reserves is found to be around -0.76 , meaning thereby, if long term debt increases by $1 \%$, then foreign exchange reserves falls by $0.76 \%$ and it is statistically significant too. Similarly, the impact of rate of interest on foreign exchange reserves is around -0.025 , which in turn implying thereby, if rate of interest increases, then debt burden increases, so the foreign exchange reserves decline. In other words, if rate of interest increases by $1 \%$, then foreign exchange reserves falls by $0.025 \%$. Since rate of interest is found to be insignificant on the basis of table 4.4 , it can safely be concluded that rate of interest as a variable has been overrated.

\section{CONCLUSION AND RECOMMENDATIONS}

The current paper has focussed on the variables which are significant and reliable determinants of foreign exchange reserves in India. By using double log regression model, the elasticity between foreign exchange reserves and its determinants have also been calculated. For the purpose of analysis, three main models namely, model A, model B and structural equation model have been used. These models have helped to find out the significance level of various variables under consideration. The four highly insignificant variables namely, oil import, non-oil import, 
external commercial borrowing and money supply, M3, have been considered for Model A but eliminated from model B. Finally, two stage least square model (2SLS) has been used. In the first stage of this model, auxiliary regression has been applied between total debt (short term debt and long term debt) and rate of interest to test the multicollinearity among them. Finally, during the second stage, on the basis of auxiliary regression the predicted values of short term debt were derived and substituted it in the structural equation model and finally it may be concluded that all the variables are coming out to be highly significant. So, it would be highly desirable for policy makers of India to consider the above mentioned significant determinants of foreign exchange reserves as the reliable determinants.

The current paper observes certain gaps in the study which can be filled up by further research using data for other emerging developing economies. The rearchers can analyse the relevant and significant determinants of foreign exchange reserves with reference to these economies. Since the present study has not considered the foreign institutional investments as it is highly volatile variable, other reasearchers may include this variable for further research.

\section{SOURCES OF FUNDING}

This research received no specific grant from any funding agency in the public, commercial, or not-for-profit sectors.

\section{CONFLICT OF INTEREST}

The author have declared that no competing interests exist.

\section{ACKNOWLEDGMENT}

None.

\section{REFERENCES}

[1] Barnichon, R. (2008), 'International Reserves and Self Insurance against External Shocks', Washington, DC: International Monetary Fund.

[2] Chowdhury, F. (2015), 'Prospects of Foreign Exchange Reserves- A Study on Bangladesh', DIU Journal of Business and Economics, Vol. 9(1), pp. 77-90.

[3] Chowdhury, M., Uddin, M., Islam, M. (2014), 'An econometric analysis of the determinants of foreign exchange reserves in Bangladesh', Journal of World Economic Research, Vol. 3 (6), pp. 72-82.

[4] Dabla-Norris, E., Kim, J., Shirono, K. (2011), 'Optimal Precautionary Reserves for Low-Income Countries: A Cost-Benefit Analysis', Washington DC: International Monetary Fund.

[5] Dooley, M., Lizondu, J., Matheison, D. (1989), 'The currency composition of foreign exchange reserves', IMF Staff Papers, Vol. 36(2), pp. 385-434.

[6] Green, R., Tom, T. (2007), 'Are high foreign exchange reserves in emerging markets a blessing or a burden?', Occasional paper no. 6, Department of the treasury, Office of International affairs.

[7] Hatase, M., Mari, O. (2009), 'Did the structure of trade and foreign debt affect reserve currency composition?', Evidence from interwar Japan European Review of Economic History, Vol. 13 (3), pp. 319-347.

[8] Hayashi, F., Sims, C. (1983), 'Nearly Efficient Estimation of Time Series Models with Predetermined, but not Exogenous, Instruments', The Econometric Society, Vol. 51(3), pp. 783-798.

[9] International Monetary Fund, International Financial Statistics, IMF Data, website of IMF, Accessed June 2017.

[10] Islam, M.S. (2009), 'An Economic Analysis of Bangladesh's Foreign Exchange Reserves', SAS Working Paper 85.

[11] Krušković, B., Maričić, T. (2015), 'Empirical Analysis of the Impact of Foreign Exchange Reserves to Economic Growth in Emerging Economies', Applied Economics and Finance, Vol. 2(1), pp. 102-108.

[12] Mohanty, M., Philip, T. (2006), 'Foreign exchange reserve accumulation in emerging markets: what are the domestic implications?' SSRN-id1632410, Bank for International Settlements, pp. 39-52. 
[13] Moore, W., Glean, A. (2016), 'Foreign exchange reserve adequacy and exogenous shocks', Applied Economics, Vol. 48(6), pp. 490-501.

[14] Ozyildirim, S., Yaman, B. (2005), 'Optimal versus Adequate Level of International Reserves: Evidence for Turkey', Applied Economics, Vol. 37(13), pp. 1557-1569.

[15] Polterovich, V., Victor, P. (2003), 'Accumulation of foreign exchange reserves and long term growth' SSRNid1751866.

[16] Ray, S. (2012), 'Foreign Exchange Reserve and its Impact on Stock Market Capitalization: Evidence from India', Research on Humanities and Social Sciences, Vol. 2 (2), pp. 46-61.

[17] Reddy, Y. (2002), 'India's foreign exchange reserves- policy, status and issues', Economic and Political Weekly, Vol. 37 (20), pp. 1906-1914.

[18] Reserve Bank of India, Database on Indian Economy, Statistics, website of RBI. Accessed June 2017.

[19] Sahu, S. (2015), 'Adequacy of India's Foreign Exchange Reserves', The Clearing Corporation of India Limited, Monthly Newsletter.

[20] Sen, P. (2005), 'India's foreign exchange reserves: An embarrasement of riches', Economic and political weekly, Vol. 40(20), pp. 2018-2019.

[21] Shrestha, P. (2016), 'Macroeconomic Impact of International Reseves', Empirical Evidence from South Asia. NRB Working Paper No. 32.

[22] Singh, C. (2005), 'Should India use Foreign Exchange Reserves for Financing Infrastructure?' Stanford Centre for International Development, Working Paper No. 256.

[23] World Bank, World Bank Data Bank, website of World Bank. Accessed June 2017.

[24] Worrel, D. (1976), 'The theory of optimal foreign exchange reserves in a developing country', Sir Arthur Lewis Institute of Social and Economic Studies, University of the West Indies, Vol. 25(3), pp. 259-279. 